
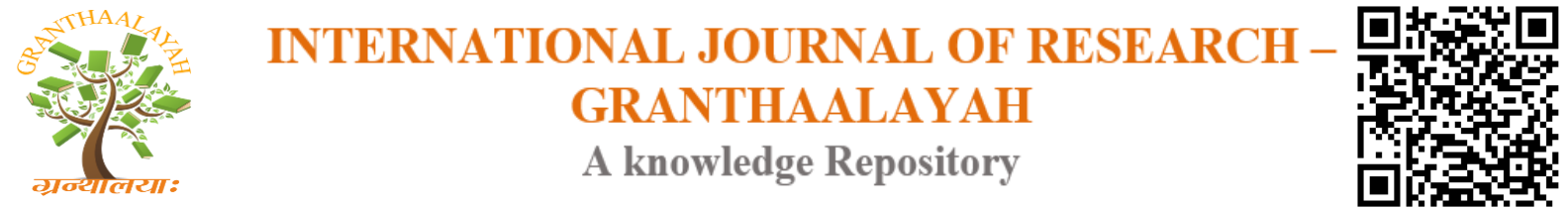

Management

\title{
AMBUSH MARKETING: THE UNOFFICIAL FREE RIDING
}

\author{
Shruti Gulati ${ }^{* 1}$ \\ ${ }^{* 1}$ Department of Commerce, Delhi University, INDIA
}

DOI: https://doi.org/10.29121/granthaalayah.v4.i9.2016.2533

\section{ABSTRACT}

Ambush Marketing has broken the stereotypical notions of the 4P'S of marketing. It has branched marketing to a totally different arena of publicity without actually paying for it directly. This usually involves conducting of marketing campaigns that seek association with a given massive events without actually providing compensation to the organizer of the event, even though there is a corporate rival as a sponsor involved. Ambush marketing include sponsorship of the event's broadcast, aggressive sponsorship of various categories of an event, and the conducting of high-profile non-sponsorship campaigns timed to coincide with the event. The big question arises to its nature as a moral act for which several legal steps are also being taken. Nonetheless ambush marketing has given scope of visibility to many startups and not so wealthy companies to free ride on the official sponsors. This research is undertaken after observation of the various sporting events which are the biggest playfield for its display. The data gathered herein is majorly secondary with help from various journals, magazines and search engines.

Keywords:

Marketing, infringement, sponsorship, ambush, official, competitors.

Cite This Article: Shruti Gulati, "AMBUSH MARKETING: THE UNOFFICIAL FREE RIDING” International Journal of Research - Granthaalayah, Vol. 4, No. 9 (2016): 45-54.

\section{INTRODUCTION}

“... thieves knowingly stealing something that does not belong to them” (Payne 1991 p24)

There is always attraction to things that are free. We may blame it to be the tendency of human beings to pounce on opportunity without actually paying or losing anything. Is it fair? Is it right to divide benefits without actually working for it monetarily? Is free riding moral? Then why at all do people take the first step? Why doesn't everyone just sit down and wait for others so as to take advantage? Well, this is what ambushers do. What is ambush marketing and is it moral, fair and legal is what shall be discussed in the following sections. Mostly ambush marketing is aimed to capitalize on the visibility of a major event through marketing campaigns that associate an advertiser with it, but without actually having paid sponsorship fees to the event's organizer so as 
to identify themselves as an official partner or sponsor. A definition offered by Sandier and Shani (1989) focuses on the objective of ambushing:

"a planned effort by an organization to associate itself indirectly with an event in order to gain at least some of the recognition and benefits that are associated with being an official sponsor" (p. 11)

\section{CONCEPT}

\section{'An attack from a hidden position'}

The Cambridge University Business English Dictionary describes the term ambush marketing as a situation wherein a company tries to advertise its products in connection with a big public event, without paying any money, although they are not one of the official sponsors.

This word is derived from the old French word 'embuschier' which indicates as a place in the woods.

For example the players wear the brand which is the official sponsors of the event and at the same time sport the can for drinking energy drink of another brand. This way, the publicity of the official sponsor gets diluted even after it being the prime brand in terms of sponsorship. It can be said that energy drink brand has ambushed behind the official sponsor and free rides on the benefits. This shall of course agitate the company who spends huge tons of money i.e. the official sponsor because it is unable to ripe the benefit of being the sole brand in limelight. They come across as pseudo sponsors.

Ambush marketing aims at earning corporate returns without actually investing that level of expense or to bother being the official sponsors. It's like piling on somebody else's money and sharing the success without actually working hard enough. Ambush marketing is not illegal but companies fear such division of gains, popularity and dilution of interest and hence are more than interested to restore the walls of security through stringent laws.

Broadly ambush marketing takes the four forms that are discussed in the upcoming section.

\section{OBJECTIVES OF THE STUDY}

1) To provide an understanding of the concept of ambush marketing

2) To discuss various types of ambush marketing.

3) To provide for alternates of ambush marketing.

4) To analyze the nature of ambush marketing.

\section{HISTORY}

Ambush marketing or ambush advertising is a marketing strategy in which an advertiser ambushes an event to compete for visibility against competing advertisers so as to gain exposure and market share. Would this all exist if there were no 'official' sponsors? 
Not really. Or maybe yes. This term was coined by marketing strategist Jerry Welsh while he was the manager of global marketing efforts with American Express in the 1980s. He stated:

"weak-minded view that competitors have a moral obligation to step back and allow an official sponsor to reap all the benefits from a special event” (Meenaghan 1996 p108).

"not only a right, but an obligation to shareholders to take advantage of such events" and that "all this talk about unethical ambushing is ... intellectual rubbish and posturing by people who are sloppy marketers" (Meenaghan 1996 p108).

Ambush marketing goes hand in hand with sporting events and it emerged as a concept that first came to light at the 1984 Los Angeles Olympics wherein it providing greater value for the sponsors to reap benefits of the mass viewership, it at the same time opened the door to ambush marketers seeking to capitalize on the event, as they were no longer able to do so legitimately. Prior to this, exclusive sponsorship hadn't been able to gather space with unlimited sponsorship ruling the front. As human tendency goes, it's the survival of the fittest, different means to break the monopoly of exclusive sponsorship came up, ambush marketing being prime of them all. Paralleling the growth with competitors gave rise to this concept. But it's wrong to say that its only associated with pulling down the competitors.

An example is Nike's actions during 1996 Games. There was no official shoe sponsor, yet Nike tried to associate with the event and was accused of ambushing the event (though it was a sponsor to various teams and governing bodies). Therefore, any definition of ambushing should not necessarily limit the positioning of ambushing marketing as only a tactic against competitors.(http://blogs.It.vt.edu/cads19932/files/2015/02/Confusion-with-Ambush Marketing.pdf)

\section{LITERATURE REVIEW}

- Gave theoretical framework of ambush marketing.

- Reviewed 125 research articles to conceptualize, synthesize and analyse its meaning, history, legality and existence so as to reach on a meaningful conclusion.

- Categorised and distinguished the ambush marketing concept into three types with various subtypes along with effective examples

- Analysed the nature of ambush marketing from different perspectives: competitors, media persons, official sponsors and brand itself.

- Proposed three broad alternates to avoid a situation of ambushing with sub alternates within them. 


\section{TYPES OF AMBUSH MARKETING}

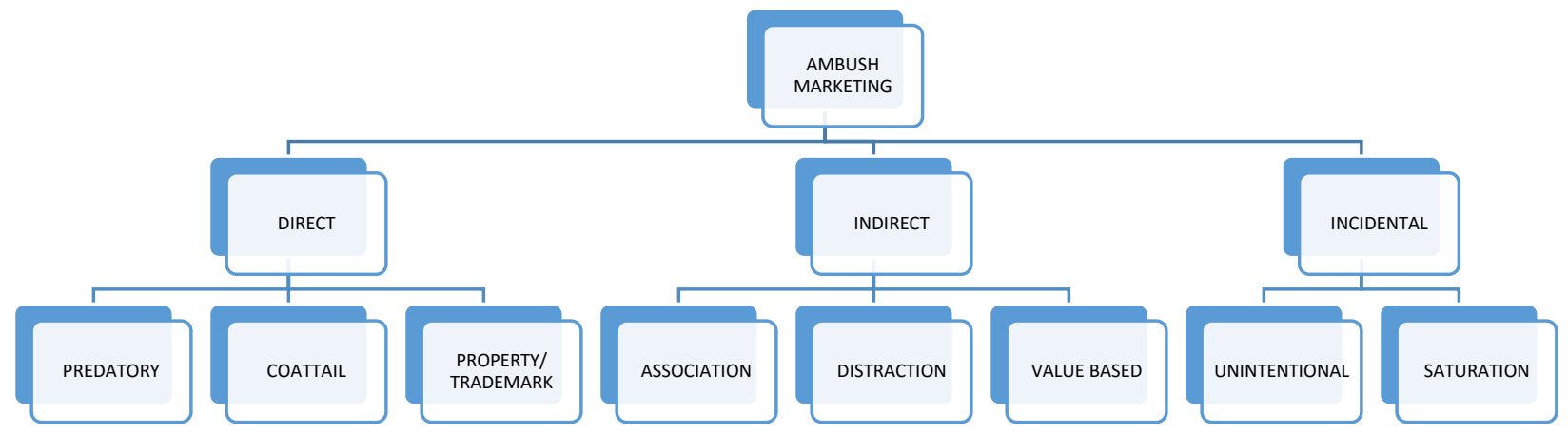

\subsection{DIRECT AMBUSH MARKETING}

\section{Predatory Ambushing}

Predatory ambushing refers to marketing tis like an attack to create confusion of the real sponsor of any event. For example, the campaign employed by AMEX against VISA during the 1994 winter games where the Official sponsor VISA was furious on the AMEX commercial with the tagline, "So if you're traveling to Norway, you'll need a passport, but you don't need a Visa."

\section{Coattail Ambushing}

Coattail ambushing involves gaining exposure through sponsoring without being individual sponsors to an individual or an event. For example, while Reebok was an official sponsor of the Atlanta Olympic Games, a rival competitor ended up snatching headlines for the event. This was when Athlete Lindford Christie wore a pair of contact lenses to a press conference that had the iconic Puma logo in the pupil which lead to that brand also being covered in the news the following day.

\section{Property or Trademark Infringement}

Property or trademark infringement is an intentional misuse or violation of the trademark of an advertiser for the purpose of diluting or confusing consumer base. For example, the organizers of the London Olympic Games had employed many officers for policing the games' brand throughout the city. There were fines on local businesses for including words like gold, bronze, or summer in their advertising, as the London Olympics believed this was an infringement on the trademark of its brand for Olympics indicative of medals and the event.

\section{Self-Ambushing}

Self-ambushing involves breaching the limits of a company's sponsorship parameters such that it infringes on other brand's sponsor's marketing or advertising. For example, in 2008 the official sponsor of the UEFA European Championships, Carlsberg, at the event gave out headbands and t-shirts with the Carlsberg logo which was not included in its sponsorship agreement, and violated the sponsorship of another company that was permitted to hand out these items. 


\subsection{INDIRECT AMBUSH MARKETING}

\section{Ambushing by association}

When there is use of imagery or terminology which is not protected by intellectual-property laws and aimed to create an illusion that an organization has links to that sporting event or property is called ambushing. For example, Kit Kat ran a competition in 2012 during European Football Championships that offered participants the chance to win 2012 Euros where they had replaced the ' $\mathrm{O}$ ' with a football. Despite it having no official link to the soccer championships.

\section{Ambush by distraction}

When there is a setup of a promotional presence at or near an event, without actually making specific reference to the event itself, its imagery, or its themes, with a view to take advantage of the public's attention toward the event and the audience members' awareness of their surroundings so it can be understood as a distraction in or around the place of event, without having any association with the event, in order to gain the attention from the event's audience and thus promote the brand's product. For example, The Open Championship in 2008 saw Bentley set up a line-up of its cars outside Hill side Golf club which was adjacent to the host course of the Open, the Royal Birkdale. This attracted great attraction from the event audience.

\section{Value based Ambush}

Tailoring by a non-sponsor of its marketing practices to appeal to the same values or involve the same themes as of the event so as to attract the audience to same attention even after being a non-sponsor. For example, in the European Championship of 2008 Puma in order to promote its football line used the tagline, June 2008: Together Everywhere, thus making a direct reference to the event of football being played that month.

\subsection{INCIDENTAL AMBUSHING}

\section{Unintentional ambushing}

This happens when the consumers incorrectly identifies a nonsponsoring company as an official sponsor due to its previous association or expectation of association with the event. For example, it is Speedo that earned a considerable attention from media as result of success of swimmers wearing LZR racer swimsuits. This portrayed Speedo as official sponsor of the Beijing Games which created a lot of confusion in the market.

\section{Saturation ambushing}

This leads to an increase the broadcast-media advertising and marketing at the time of an event but make no reference to the event itself and avoid making of associative imagery or suggestion relating to an event. For example, during the Beijing Olympics Lucozade had indulged into aggressive marketing of its products much above its standard marketing featuring athletes and many sports significantly. Saturation ambushing merely capitalizes on the increased broadcast media attention and television audiences that is around an event. 


\section{FAMOUS CASES OF AMBUSH MARKETING WORLD WIDE}

\section{NON SPORTING CASES}

- Rona recycling Apple's leftover paint

Here the advertisement read "we recycle leftover paint." Where the add was placed just below Apple's iPod nano billboard near the Jacques Cartier Bridge in Montreal.

- Fiat 500 parked outside Volkswagen's Headquarters

This lead to Fiat photo bombing the view at the Swedish Headquarters in the Google Street View 2012

- Newcastle mocking Stella's choice

At Newcastle's "No Bollocks" campaign, the beer makers placed a billboard directly below one from rival Stella Artois mocking the use of the chalice.

- Samsung slings apple for below the price

While in 2011 mobile giant Samsung launched its flagship SII at the same time of its competitor Apple's 4S. To divert attention Samsung put up a pop shop selling the phone for a mere AUS \$2 despite it being priced for AUS \$2 in Sydney for 3 days.

- Billboard war between Audi and BMW

In 2009, both German automakers Audi and BMW got into an infamous billboard war in Santa Monica, Calif where Audi set up a billboard for its A4 with the words, "Your move, BMW." And, BMW responded with a picture of its M3 and the "Checkmate."

- WePay vs PayPal

During that time, PayPal was paying the price for "freezing" customer accounts, and during a PayPal developer conference, WePay left them a little sarcastic gift. They froze money inside a massive chunk of ice and threw it to the front doors of the conference with a message: "PayPal freezes accounts - unfreeze your money"

\section{SPORTING EVENTS CASES}

- Kodak and Fuji: the origin

Fuji won the bid during the Olympics of 1984 in Los Angeles, leaving a frustrated Kodak sponsoring the US broadcast. The tactic worked as the public did consider that Kodak was an official Olympic sponsor leaving confusion.

- Paddy Power; Player striptease at Euro 2012

Nicklas Bendtner after scoring his second goal, proudly lowered his shorts to his knees while showcasing his underpants branded with Irish bookmaker Paddy Power's logo which indeed got them great attention.

- Dr Dre Beats headphones in Olympics 2012

The rapper sent headphones to numerous athletes and even made special editions for team GB branded with union flag colours. The athletes wore them, posed for cameras with them and tweeted about them too. The company saw a 42 per cent increase in sales post the Olympics event.

\section{- Nike in various Olympics}

In 1992, when Reebok was the official sponsor of the Olympic Dream Team. But every player covered up the Reebok logos on their tracksuits with American flags, and Nike held its own 
press conference with players from the team. In 1996, Nike put a billboard over Atlanta's Olympic Park, where it was also not a sponsor.

Before the 2010 World Cup sponsored by Adidas, Nike put out a lengthy online viral video of its own featuring many of the players, which many remember more than Adidas' Star Wars themed ad. Later Nike went to Johannesburg and put up an interactive installation on the city's Life Centre, $4^{\text {th }}$ largest building.

- Bavaria Beer in World Cup

Budweiser being the official beer of the 2010 World Cup, saw during the Holland v Denmark match, 36 attractive ladies wearing orange dresses bearing the Bavaria Beer logo were ejected en masse. This saw the two alleged organisers being arrested by South African police and football pundit Robbie Earle, to whom the seats were originally allocated, and was fired by ITV.

\section{- Burger King and McDonald's}

Burger King sponsored the national Olympic team of the United Kingdom when McDonald's was an official sponsor of the Olympic Games held in 1996.

\section{IS AMBUSH MARKETING GOOD?}

Ambush marketing has polarised opinion over the 25 years of its existence. Derided by some as a parasitic practice that devalues both the brand of a sports property and the official sponsorship associations it has in place, it is lauded by others as creative opportunism that fuels interest in the sports property it is piggy-backing. What is without question, however, is that the practice has created some of sport's most commercially memorable moments.

(http://www.sportspromedia.com/notes_and_insights/rise_of_the_pseudo-

sponsors_a_history_of_ambush_marketing)

'everybody wins and gets free media attention'

Be it consumers, distributors, media persons or channels and agencies, everyone gets a piece of the cake. Nobody actually loses while ambushing. It's all about who gets the higher stakes.

Suddenly the brands involved are the talk of the town. Both the companies hence face a revenue gain. Distribution channels are energised so are media channels enlightened with the attention. There is gain in store for everyone.

\section{IS AMBUSH MARKETING ETHICAL? MORAL? FAIR?}

Sponsors and event organisers view ambush marketing as immoral, unethical and, sometimes, illegal, alleging that such a practice leads to threat of integrity and the future of great events. Sponsors affirm that this kind of conduct diminishes the effectiveness of their promotional efforts, and event hence organisers fear that it might lead to diminishing the chance of attracting high-level sponsors, jeopardising the realisation of the massive event itself.

As explained above the cases of ambush marketing, companies involved in sub-category sponsorship have not necessarily engaged in illegal behaviour. Although official sponsors may see the appearance of rivals' insignia at an event as leading to confusion, this argument overlooks the fact that rivals have the right to promote their sponsorship associations and that 
right can't be taken away in light of ambushing singly. Disputes between Reebok, who was official apparel supplier to the US team at the 1992 Olympics, and Nike, who contracted the US track and field team to wear Nike clothing when competing have illustrated this issue.

Reebok considered Nike guilty of stealing exposure and publicity they believe they had purchased when they obtained the apparel sponsorship for the entire U.S. team. However, Nike argued they simply exploited a legitimate sponsorship opportunity open to them. Moreover, Nike's contracts with some of the athletes, for example Michael Johnson, existed well before the 1992 Olympics. Overall, Reebok's involvement with the U.S. Olympic team did not prevent Nike from finding ways to publicise its relationships with athletes and athletics. The ability to exploit these relationships was constrained only by the legally binding agreements that existed between individual athletes, teams, associations, governing bodies and event owners. (http://faculty.mu.edu.sa/public/uploads/1358095215.1852A\%20Critical\%20Review.pdf)

Davis (1996) reports that Nike manager Mark Pilkenton rationalised these actions by stating: "...we feel like in any major sporting event, we have the right to come in and give our message as long as we don't interfere with the official proceedings".

But at the same time the term sponsorship itself is indefinite. As Sandler and Shani have noted that the definitions of sponsorship "are ones of convenience and reflect what a specific organization prefers to consider as sponsorship" (Sandler \& Shani, 1989, p. 11)

As much as there is question of free riding it is true behind the justification of being opportunists, there is an attempt to escape the responsibilities and cost associated with being official. To think of it, as long as it's not harming the parties involved, it can't be called unethical. Wherein there is question about it being fair, the division of attention or monetary profits to the ambushers is illegitimate yet not illegal. This situation is arising more so because of loopholes in the system, legislations and marketing.

\section{SOLUTIONS SUGGESTED}

To avoid a situation as ambushing, the following are certain suggestions:

PREVENTIVE MEASURES
EDUCATIONAL PROGRAMMES
COMARKETING

\section{Preventive measures}

Control the sale or distribution of souvenirs, promotional material that might be used by unauthorised competitors to promote their own products/services or to try to create an association with the event. Shops can be monitored, commercial establishments and electronic 
commerce websites so as to control the use and sale of unlicensed products containing marks related to the event. Disguised groups of fans should be prevented from using clothes or posters inside the stadiums with the purpose of promoting competitors' trademark. A conscious effort to abstain from wearing clothes and accessories containing the mark of unauthorised competitors, or consuming such competitors' products at the place of the event should be made.

\section{Educational programmes}

Shani \& Sandler (1999) recommend the use of an education programme, designed to ensure consumers are aware that not all advertisers are official sponsors of an event. The IOC has developed aggressive advertising campaigns that castigate alleged ambushers as cheats that deserve public approbation. These advertisements suggest that ambushers are attempting to dupe the public and freeload on the values of the official Olympic movement by undermining the rights secured by their competitors. However, it is not clear whether this advertising clarifies the status of the official sponsors; ironically, it could actually reinforce awareness of the rival. (http://faculty.mu.edu.sa/public/uploads/1358095215.1852A\%20Critical\%20Review.pdf)

\section{Co-marketing}

If possible with events, co-marketing should be adopted so as justice and rewards are given duly to all and not one sponsor. This way questions of free riding shall not arrive.

This type of joint arrangement can help in free competition and greater mobility within categories and sub categories.

\section{CONCLUSION}

To conclude ambush marketing is seen differently by different people. Where one set of people believe it to be a zero sum game the others think it's a positive one. Certain category believes it to be snatching their bit of attention, wherein some believe regulating sales or revenues. Ambush marketing might have seen sudden increase due to rising social media in terms of tweets, likes and views the traditional theorists believe it be increasing the viewership count on the national or international TVs. This situation has arisen due to many and who is to be blame is a matter of choice and opinion. Where some might feel the lack of legislation, the others might blame sudden social media and maybe others would like to attribute the confusion at events as one. The fact that a thief is a kleptomaniac or actually poor, he, free rides on the wealthy because they leave some loopholes or because he is paid is a personal judgement!

\section{REFERENCES}

[1] Payne M (1991). Ambush marketing: Immoral or imaginative practice. Paper presented at Sponsorship Europe '91 Conference, Barcelona, Spain

[2] http://go.galegroup.com/ps/anonymous?id=GALE\%7CA16549008\&sid=googleScholar $\& v=2.1 \& i t=r \&$ linkaccess $=$ fulltext $\& i s s n=00218499 \& p=A O N E \& s w=w \&$ authCount $=1 \& i$ sAnonymousEntry=true

[3] http://dictionary.cambridge.org/dictionary/english/ambush-marketing

[4] Sandler D \& Shani D (1989). Olympic Sponsorship vs "ambush" marketing: Who gets the gold? Journal of Advertising Research, 29, 9-14. 
[5] Shani D \& Sandler D (1998). Ambush marketing: Is confusion to blame for the flickering of the flame? Psychology and Marketing, 15 (4), 367-383.

[6] Shani D \& Sandler D (1999). Counter attack: heading off ambush marketers. Sports Marketing, 18 January, 10.

[7] Meenaghan $T$ (1994). Point of view: Ambush marketing - Immoral or imaginative practice? Journal of Advertising Research, 34 (3), 77-88.

[8] Meenaghan T (1996). Ambush marketing - A threat to corporate sponsorship. Sloan Management Review, 38, 103-113.

[9] Meenaghan $T$ (1998a). Ambush marketing: Corporate strategy and consumers' reactions. Psychology and Marketing, 15 (4), 305-322.

[10] Meenaghan T (1998b). Current developments and future directions in sponsorship. International Journal of Advertising, 17 (1), 3-28.

[11] http://www.peacepalacelibrary.nl/2012/08/ambush-marketing-drinking-coca-colawearing-adidas/

[12] http://www.sportspromedia.com/notes_and_insights/rise_of_the_pseudosponsors_a_history_of_ambush_marketing

[13] http://yourbusiness.azcentral.com/four-types-ambush-marketing-14038.html

[14] http://s3.amazonaws.com/academia.edu.documents/44135204/Ambush_Mktg_Farrelly_J AR_2005.pdf?AWSAccessKeyId=AKIAJ56TQJRTWSMTNPEA\&Expires $=1472726395 \&$ Signature $=q A S u M w R d J 2 j A J 1$ tMPqe2\%2F8MTnYA\%3D\&response-contentdisposition=inline $\% 3 B \% 20$ filename\%3DDefending_the_CoBranding_Benefits_of_Sp.pdf

[15] http://www.galalaw.com/files/AmbMktgPush.pdf

[16] http://apjor.com/files/1383062412.pdf

[17] http://marketing-bulletin.massey.ac.nz/V14/MB_V14_A1_Crow.pdf

[18] http://blogs.lt.vt.edu/cads19932/files/2015/02/Confusion-with-Ambush-Marketing.pdf

[19] http://www.businessinsider.com/best-ambush-marketing-campaigns-20126?IR=T\#ambush-marketing-is-likely-to-be-a-problem-at-the-london-olympics-12

[20] http://realbusiness.co.uk/article/27377-8-great-ambush-marketing-campaigns/page:2

[21] http://www.promoveritas.com/Blog/Best-Ambush-Marketing-Campaigns\#

[22] http://www.worldipreview.com/contributed-article/ambush-marketing-immoral-andunethical-or-justifiable 